\title{
EXPLORATION OF PREHISTORIC SITES IN THE KARAMA WATERSHED, WEST SULAWESI, INDONESIA: FROM EARLY OCCUPATION UNTIL THE METAL AGE
}

\author{
Fakhri $^{1}$, Suryatman ${ }^{2}$, Budianto Hakim $^{3}$, Ratno Sardi $^{4}$
}

Balai Arkeologi Makassar

${ }^{1}$ fakhri.archaeology@yahoo.co.id, ${ }^{2}$ suryatman.arkeologi@gmail.com, ${ }^{3}$ budiantohakim@yahoo.co.id \& ${ }^{4}$ nuno.balar@hotmail.com

\section{ABSTRACT}

This study presents new data on prehistoric occupation in the Karama River catchment, obtained during 2014 with the aid of a grant from the Granucci Fund for Archaeological Research in Indonesia and East Timor. The results are linked to previous research in the valley, with the intention of reconstructing prehistoric occupation patterns from early times until the Metal Age.

\section{INTRODUCTION}

The Karama is one of the major rivers rising in the mountains of West Sulawesi, with a width of 50 to 100 metres. It flows from a source in the western mountains of Tana Toraja, passes through the town of Kalumpang, and empties into Makassar Strait at Sikendeng (Simanjuntak 1994: 2) (Figure 1). Some known sites in regions already explored along the banks of the river include Minanga Sipakko, Kamansi (Kamassi) (Simanjuntak 1994), Palemba, Sikendeng, Pantaraan (Anggraeni 2012; Anggraeni et al. 2014), Salu Makula, Kaindoro (Anon. 2011, 2012), and many others.

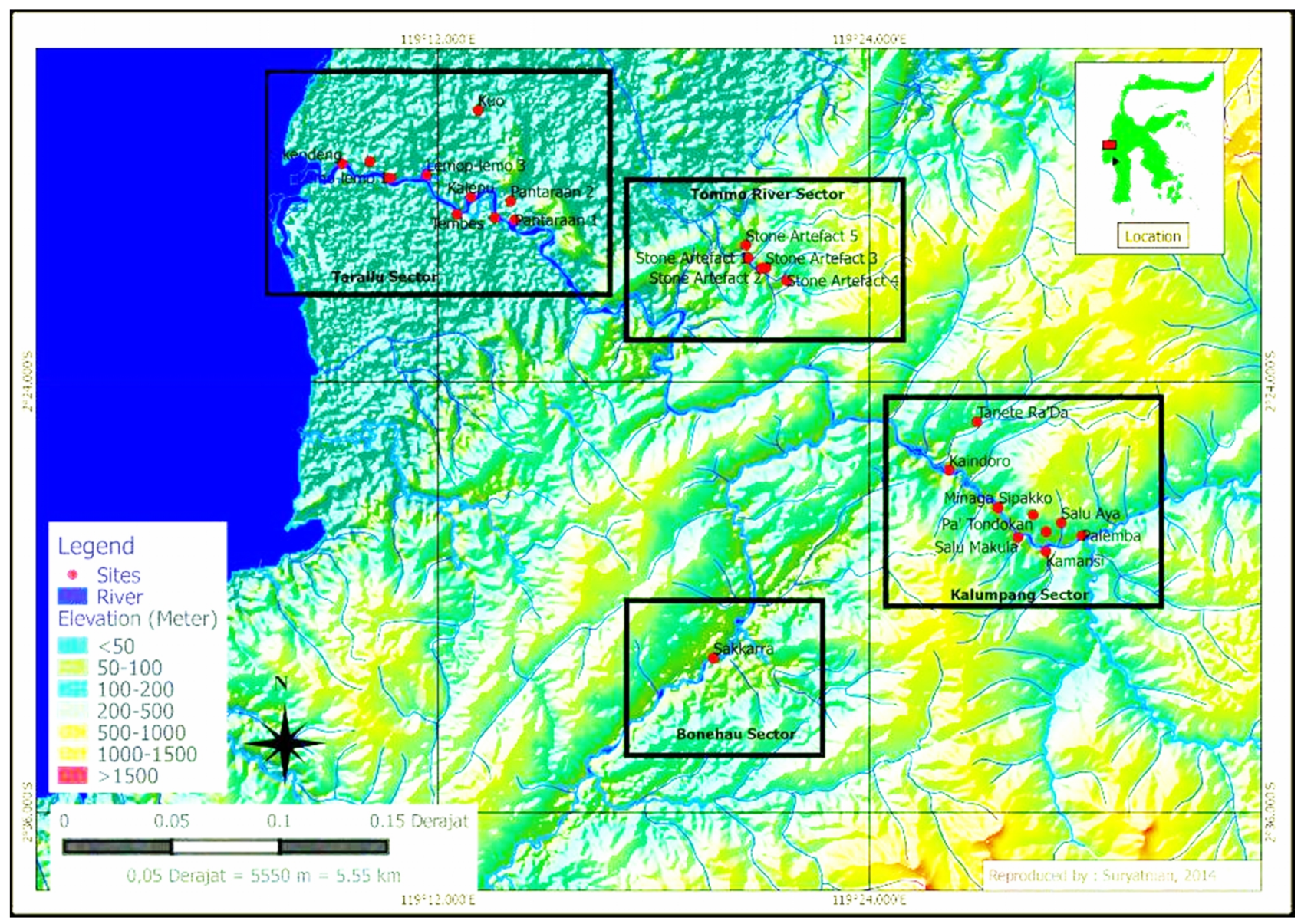

Figure 1: Surveyed areas and site locations in the Karama Watershed, West Sulawesi. 
Table 1: Karama Valley sites listed by survey zone and administrative region.

\begin{tabular}{|c|c|c|c|c|}
\hline Zone and Site & & $\mathbf{N}$ & $\mathbf{E}$ & Elevation $(\mathrm{m})$ \\
\hline \multicolumn{5}{|l|}{ TARAILU SECTOR } \\
\hline Sikendeng & Desa Pangale, Kec. Pangale, Kab. Mamuju & $02^{\circ} 17^{\prime} 56.0^{\prime}$ & $119^{\circ} 09^{\prime} 20.2^{\prime}$ & 26 \\
\hline Lattibung & Desa Pangale, Kec. Pangale, Kab. Mamuju & $02^{\circ} 17^{\prime} 52.0^{\prime}$ & $119^{\circ} 10^{\prime} 05.2^{\prime}$ & 8 \\
\hline Lemo-Lemo 1 & Desa Lemo-Lemo, Kec. Pangale, Kab. Mamuju Tengah & $02^{\circ} 18^{\prime} 19.3^{\prime}$ & $119^{\circ} 10^{\prime} 36.3^{\prime}$ & 10 \\
\hline Lemo-Lemo 2 & Desa Lemo-Lemo, Kec. Pangale, Kab. Mamuju Tengah & $02^{\circ} 18^{\prime} 19.9^{\prime}$ & $119^{\circ} 10^{\prime} 41.1^{\prime}$ & 20 \\
\hline Lemo-Lemo 3 & Desa Lemo-Lemo, Kec. Pangale, Kab. Mamuju Tengah & $02^{\circ} 18^{\prime} 14.5^{\prime}$ & $119^{\circ} 10^{\prime} 40.9^{\prime}$ & 20 \\
\hline Bukit Kuo & Desa Kuo, Kec. Pangale, Kab. Mamuju & $02^{\circ} 16^{\prime} 26.2^{\prime}$ & $119^{\circ} 13^{\prime} 06.9^{\prime}$ & 44 \\
\hline Pantaraan 1 & Desa Pantaraan, Kec. Tommo, Kab. Mamuju & $02^{\circ} 19^{\prime} 29.7^{\prime}$ & $119^{\circ} 14^{\prime} 08.0^{\prime}$ & 15 \\
\hline Pantaraan 2 & Desa Pantaraan, Kec. Tommo, Kab. Mamuju & $02^{\circ} 18^{\prime} 59.0^{\prime}$ & $119^{\circ} 14^{\prime} 00.5^{\prime}$ & 18 \\
\hline Salo Mabongi & Desa Losso, Kec. Sampaga, Kab. Mamuju & $02^{\circ} 19^{\prime} 25.5^{\prime}$ & $119^{\circ} 13^{\prime} 35.5^{\prime}$ & 25 \\
\hline Tembes & Desa Losso, Kec. Sampaga, Kab. Mamuju & $02^{\circ} 19^{\prime} 17.7^{\prime}$ & $119^{\circ} 12^{\prime} 31.2^{\prime}$ & 30 \\
\hline Kalepu & Desa Kalepu, Kec. Tommo, Kab. Mamuju & $02^{\circ} 18^{\prime} 51.8^{\prime}$ & $119^{\circ} 12^{\prime} 55.3^{\prime}$ & 31 \\
\hline \multicolumn{5}{|c|}{ TOMMO RIVER SECTOR } \\
\hline Tommo valley & Desa Campaloga, Kec. Tommo, Kab. Mamuju & $2^{\circ} 20^{\prime} 33.1^{\prime \prime}$ & $119^{0} 20^{\prime} 37.5^{\prime \prime}$ & 90 \\
\hline \multicolumn{5}{|l|}{ BONEHAU SECTOR } \\
\hline Sakkarra & Desa Bone Hau, Kec. Bone Hau, Kab. Mamuju & $02^{\circ} 31^{\prime} 42.0^{\prime}$ & $119^{\circ} 19^{\prime} 40.1^{\prime}$ & 84 \\
\hline \multicolumn{5}{|c|}{ KALUMPANG SECTOR } \\
\hline Pattondokan & Desa Kalumpang, Kec. Kalumpang, Kab. Mamuju, Kab. Mamuju & $02^{\circ} 27^{\prime} 42.0^{\prime}$ & $119^{\circ} 28^{\prime} 33.7^{\prime}$ & 280 \\
\hline Salu Makula & Desa Kalumpang, Kec. Kalumpang, Kab. Mamuju, Kab. Mamuju & $02^{\circ} 28^{\prime} 20.4^{\prime}$ & $119^{\circ} 28^{\prime} 09.6^{\prime}$ & 94 \\
\hline Palemba & Desa Kalumpang, Kec. Kalumpang, Kab. Mamuju, Kab. Mamuju & $02^{\circ} 28^{\prime} 17.1^{\prime}$ & $119^{\circ} 29^{\prime} 55.2^{\prime}$ & 114 \\
\hline Kaindoro & Desa Kalumpang, Kec. Kalumpang, Kab. Mamuju, Kab. Mamuju & $02^{\circ} 26^{\prime} 28.0^{\prime}$ & $119^{\circ} 26^{\prime} 13.4^{\prime}$ & 54 \\
\hline Kamansi (Kamassi) & Desa Kalumpang, Kec. Kalumpang, Kab. Mamuju, Kab. Mamuju & $02^{\circ} 28^{\prime} 43.3^{\prime}$ & $119^{\circ} 28^{\prime} 54.8^{\prime}$ & 95 \\
\hline Minanga Sipakko & Desa Kalumpang, Kec. Kalumpang, Kab. Mamuju, Kab. Mamuju & $02^{\circ} 27^{\prime} 29.8^{\prime}$ & $119^{\circ} 27^{\prime} 34.9^{\prime}$ & 95 \\
\hline
\end{tabular}

Given the importance and size of the river, it will be interesting to examine site distributions from initial occupancy until the Metal Age. In addition, data retrieval from former settlements along the Karama is now essential, given that many are threatened by river bank erosion, and also by plans to extract hydroelectric power from the river through dam construction.

\section{SURVEY RESULTS}

For survey purposes, the valley is divided into four sectors that have already been searched; Tarailu on the lower part of the main Karama river to the west, the Tommo River to the north, a sector of the Bonehau River to the south, and the region around Kalumpang township to the east. 19 sites are now known from these four regions (Figure 1; Tables $1 \& 2$ ), both from earlier surveys and from the present one.



Figure 2: Flaked artefacts from Kuo.

The largest number occurs in the Tarailu sector, where the majority are located not far from the river on small hilltops. In this sector, Bukit Kuo differs from the others in being quite far from the river, and in having a pre-ceramic assemblage of flaked stone artifacts (Figure 2, and see also Anggraeni 2012).

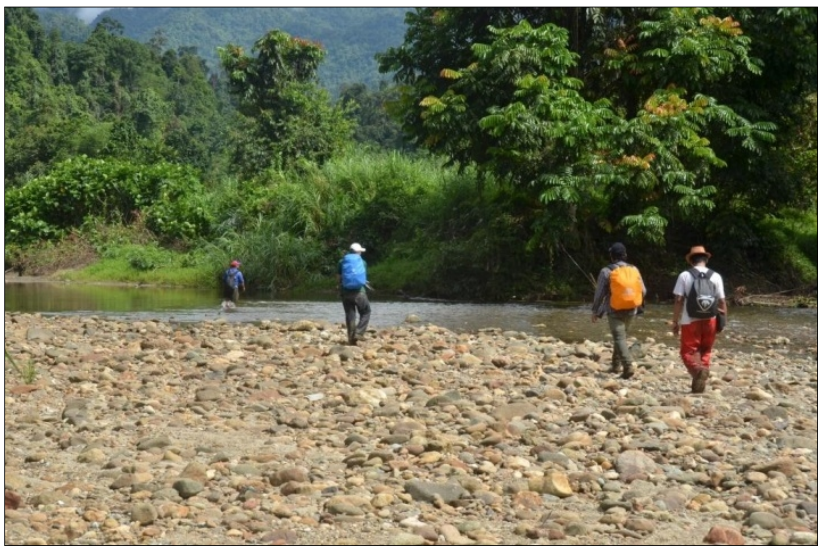

Figure 3: The Tommo Valley.

The Tommo River has pebble beds that might have served as raw material sources (Figure 3), and surface collected stone artifacts from this region include a steep-edged flake tool and a biface, both from a small hilltop close to the river (Figures $4 \& 5$ ). However, the stone artefacts here were not concentrated, and were probably not in situ.



Figure 4: Steep-edged flake tool from the Tommo Valley. 


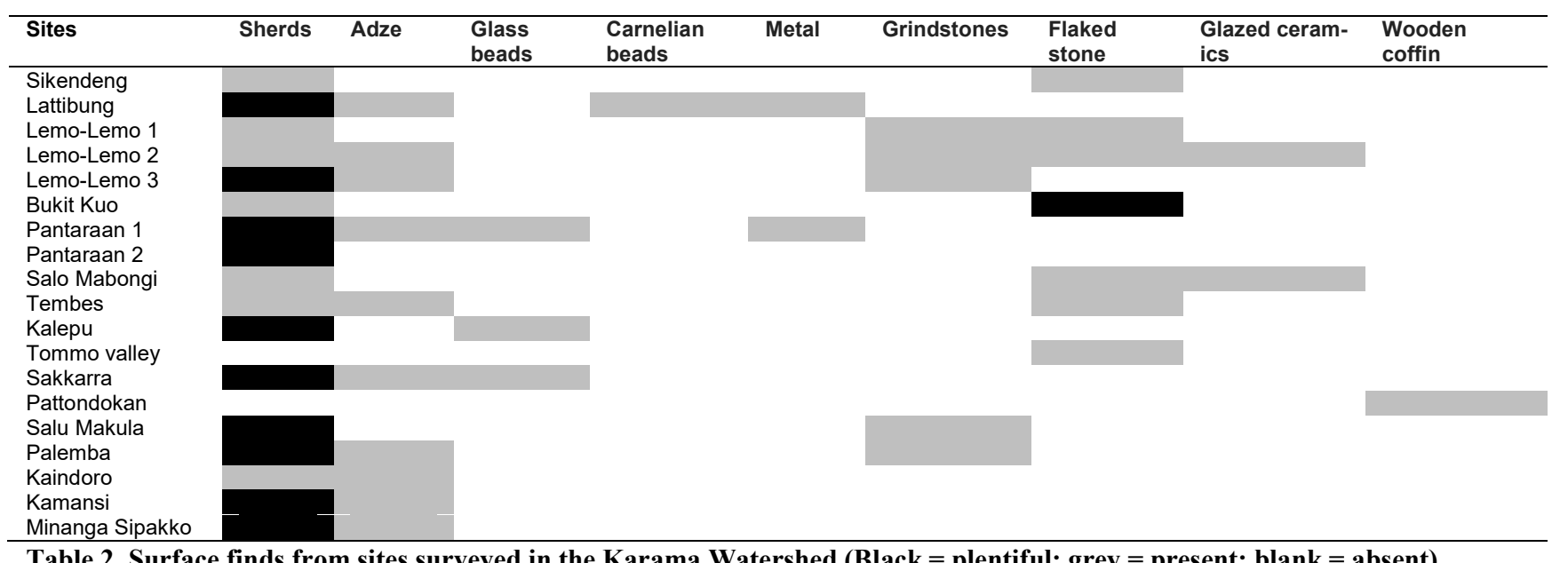

Table 2. Surface finds from sites surveyed in the Karama Watershed (Black = plentiful; grey = present; $b l a n k=$ absent $)$.

Sakkarra is another hilltop site near the Bonehau River in the Bonehau sector (Figure 6). Surface finds consist of pottery, lithics, adze fragments, a stone barkcloth beater fragment and monochrome glass beads (Figures 7-9). The material resembles closely that from the other better-known sites in the Tarailu sector (Anggraeni 2012). A stone axe was also found by one of the villagers on the river bank close to the site (Figure 10).

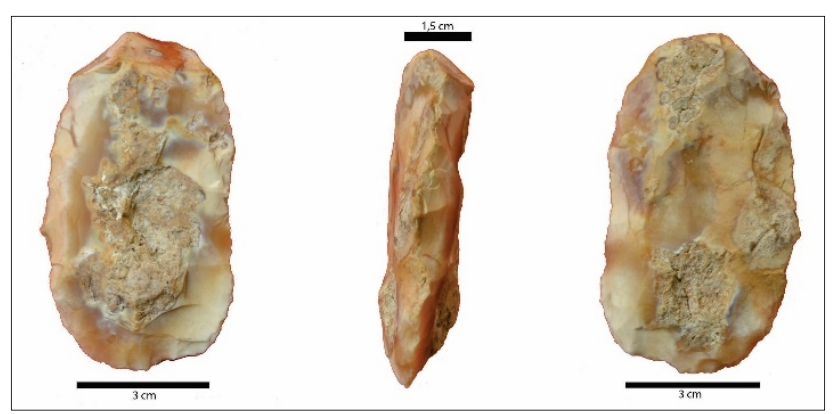

Figure 5: Bifacial artefact from the Tommo Valley.

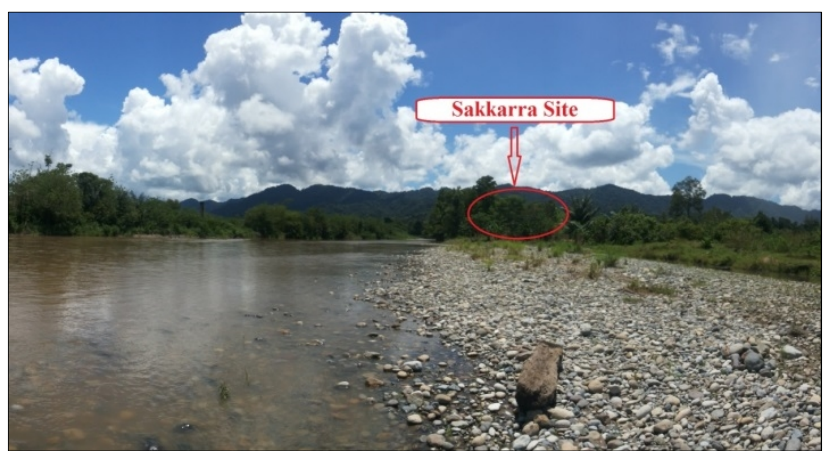

Figure 6: The location of Sakkarra on the Bonehau River.



Figure 7: Pottery concentration at Sakkarra.



Figure 8: Monochrome glass beads from Sakkarra.

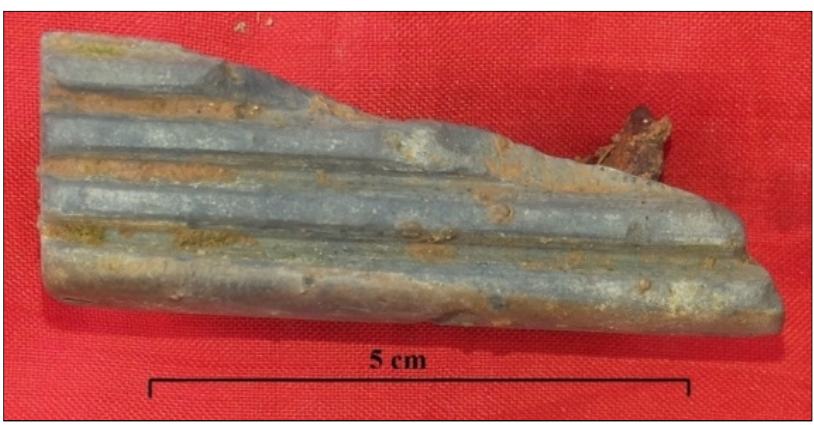

Figure 9: Stone barkcloth beater fragment from Sakkarra. 


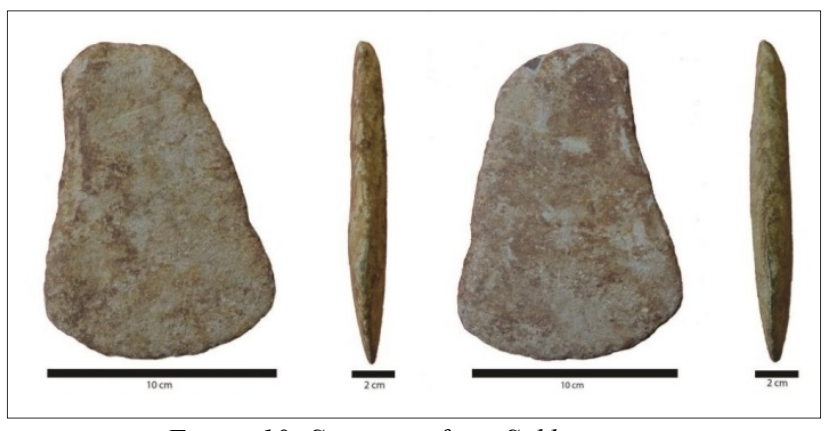

Figure 10: Stone axe from Sakkarra.



Figure 11: The excavation location at Sakkarra.

Table 3: Distributions of selected artefact categories by depth below surface (spit 1) at Sakkarra.

\begin{tabular}{|c|c|c|c|c|c|c|}
\hline $10 \mathrm{~cm}$ spit & Sherds by weight (gm) & Iron slag (gm) & Beads (no.) & Stoneware (no.) & Glass bracelet (no.) & Ground stone (no.) \\
\hline 1 & 0 & 0 & & & & \\
\hline 2 & 120 & 56 & & & & \\
\hline 3 & 1618 & 0 & & 2 & & \\
\hline 4 & 1031 & 0 & & 1 & & \\
\hline 5 & 1549 & 0 & & & & \\
\hline 6 & 8454 & 145 & & & & \\
\hline 7 & 16857 & 0 & 4 & & 1 & \\
\hline 8 & 9295 & 0 & 2 & & & \\
\hline 9 & 14218 & 428 & 1 & & & \\
\hline 10 & 2590 & 87 & & & & 5 \\
\hline 11 & 3400 & 0 & & & & 5 \\
\hline 12 & 654 & 0 & & & & \\
\hline 13 & 328 & 0 & & & & \\
\hline 14 & 486 & 0 & & & & \\
\hline 15 & 0 & 0 & & & & \\
\hline 16 & 31 & 0 & & & & \\
\hline 17 & 0 & 0 & & & & \\
\hline 18 & 0 & 0 & & & & \\
\hline Total & 60,631 & 715 & 7 & 3 & 1 & 10 \\
\hline
\end{tabular}



Figure 12: Sakkarra site map 




Figure 13: The stratigraphy of the Sakkarra site.

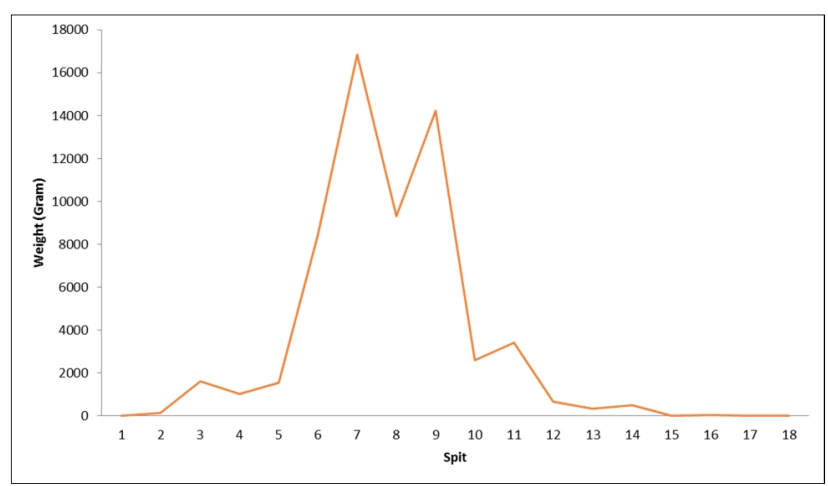

Figure 14: The frequency of sherds by $10 \mathrm{~cm}$ spit within the Sakkara excavation

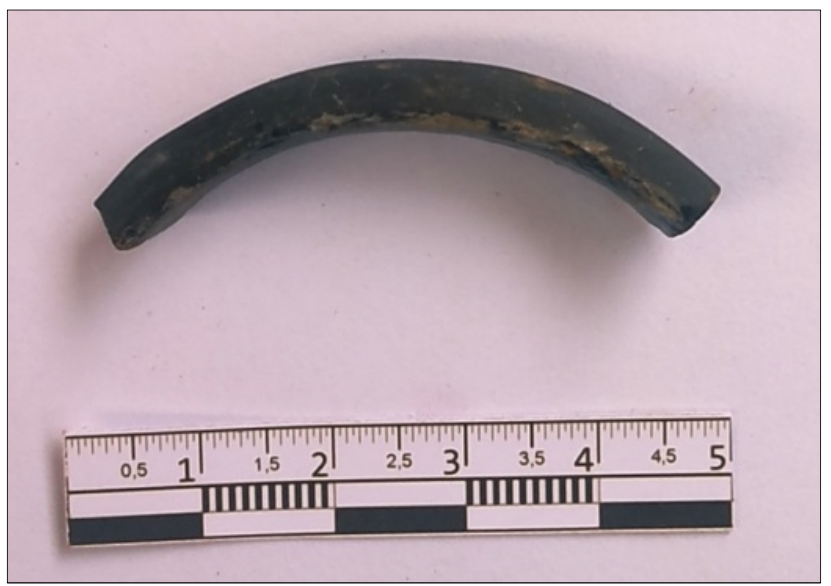

Figure 15: Glass bracelet from spit 7, Sakkarra.

Table 4: Radiocarbon dates from Sakkarra (ANU Laboratory).

\begin{tabular}{lllll}
\hline $\begin{array}{l}\text { Sample } \\
\text { code }\end{array}$ & $\begin{array}{l}\text { Dated } \\
\text { Material }\end{array}$ & Spit/Depth & 14C age & $\begin{array}{l}\text { Calibrated } \\
\text { Dates } \\
\text { BC/AD }\end{array}$ \\
\hline $\begin{array}{lllll}\text { S-ANU } \\
\text { 39336 }\end{array}$ & Charcoal & Spit 8/90-100 cm & 2000 BP & $111 \mathrm{BC}-$ \\
$\begin{array}{l}\text { S-ANU } \\
\mathbf{3 9 3 3 7}\end{array}$ & Charcoal & Spit $9 / 100-110 \mathrm{~cm}$ & $2040 \mathrm{BP}$ & $\begin{array}{l}\text { AD 83 } \\
172 \mathrm{BC}-\end{array}$ \\
\hline
\end{tabular}

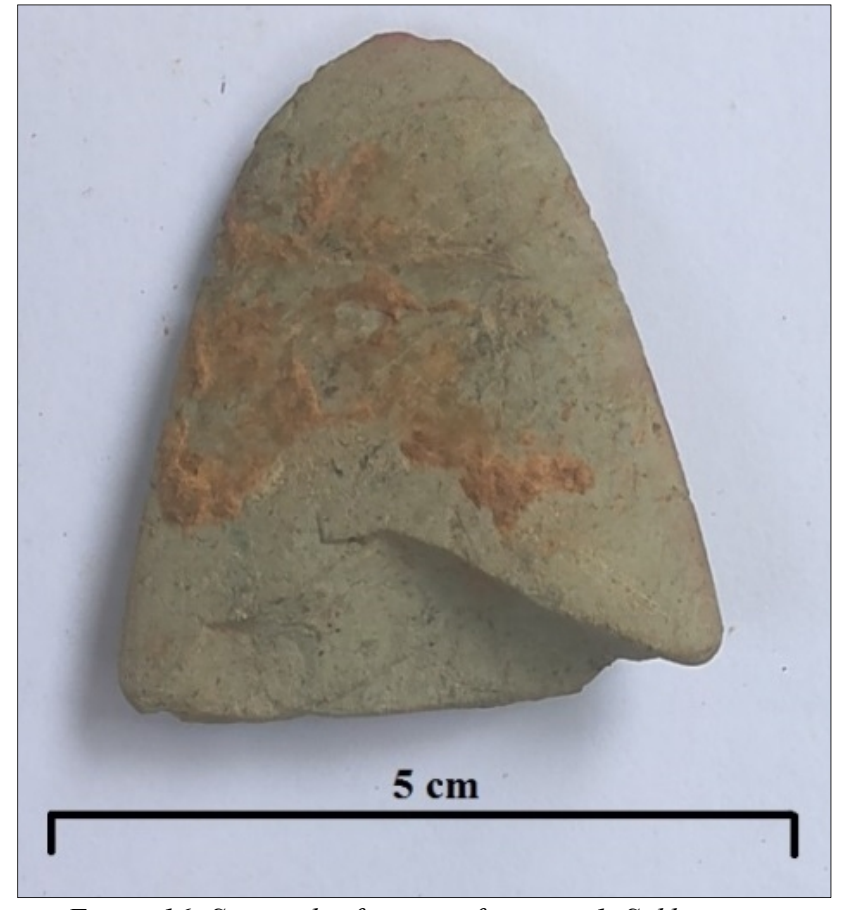

Figure 16: Stone adze fragment from spit 1, Sakkarra.

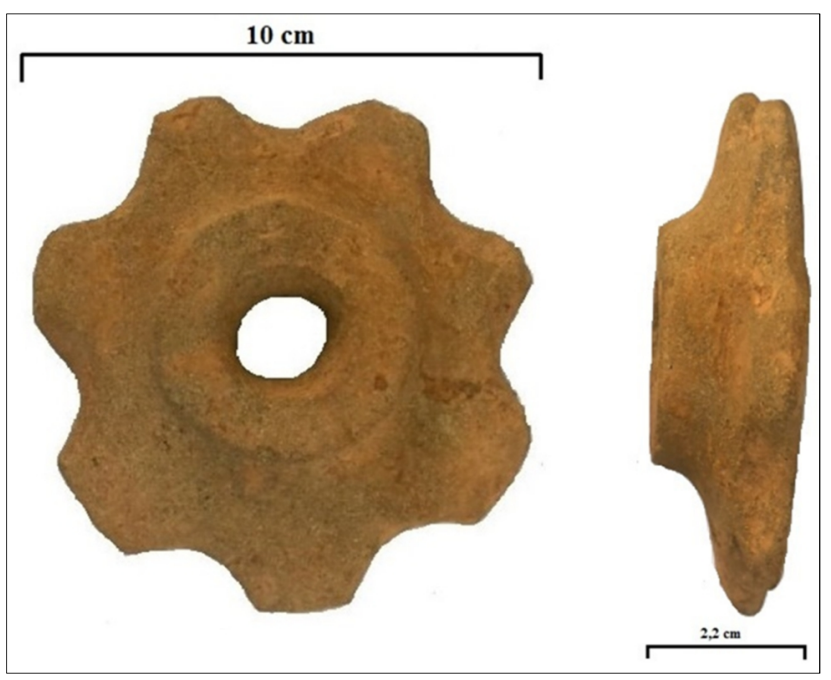

Figure 17: A star-shaped mace-like sandstone object from Sakkarra spit 11.

\section{THE SAKKARRA EXCAVATION RESULTS}

Sakkarra was chosen for excavation because of its diverse surface finds and because it was also the first site to be found in the Bonehau sector. The site is also threatened by gold mining, which is how it was discovered in the first place. Currently, mining has ceased due to low output, but the land is still contracted to the miners for possible future exploitation. The site was excavated by $10 \mathrm{~cm}$ spits in $1 \times 1 \mathrm{~m}$ squares, with spit 1 being dug to $30 \mathrm{~cm}$. Square T2 S1 was terminated at a depth of two metres in sterile soil. Only one cultural layer was present in the site (Figure 11-13), comprising a dark brown silt $(2.5 \mathrm{Y} 3 / 3)$ between spits 6 and 11 . The two ${ }^{14} \mathrm{C}$ dates listed in Table 4 suggest a date for the 
Table 5: Rim diameters and maximum body thicknesses $(\mathrm{cm})$ for the vessel types drawn in Figure 18.



Figure 18: Reconstructed pottery profiles from Sakkarra (drawing by Suryatman). 


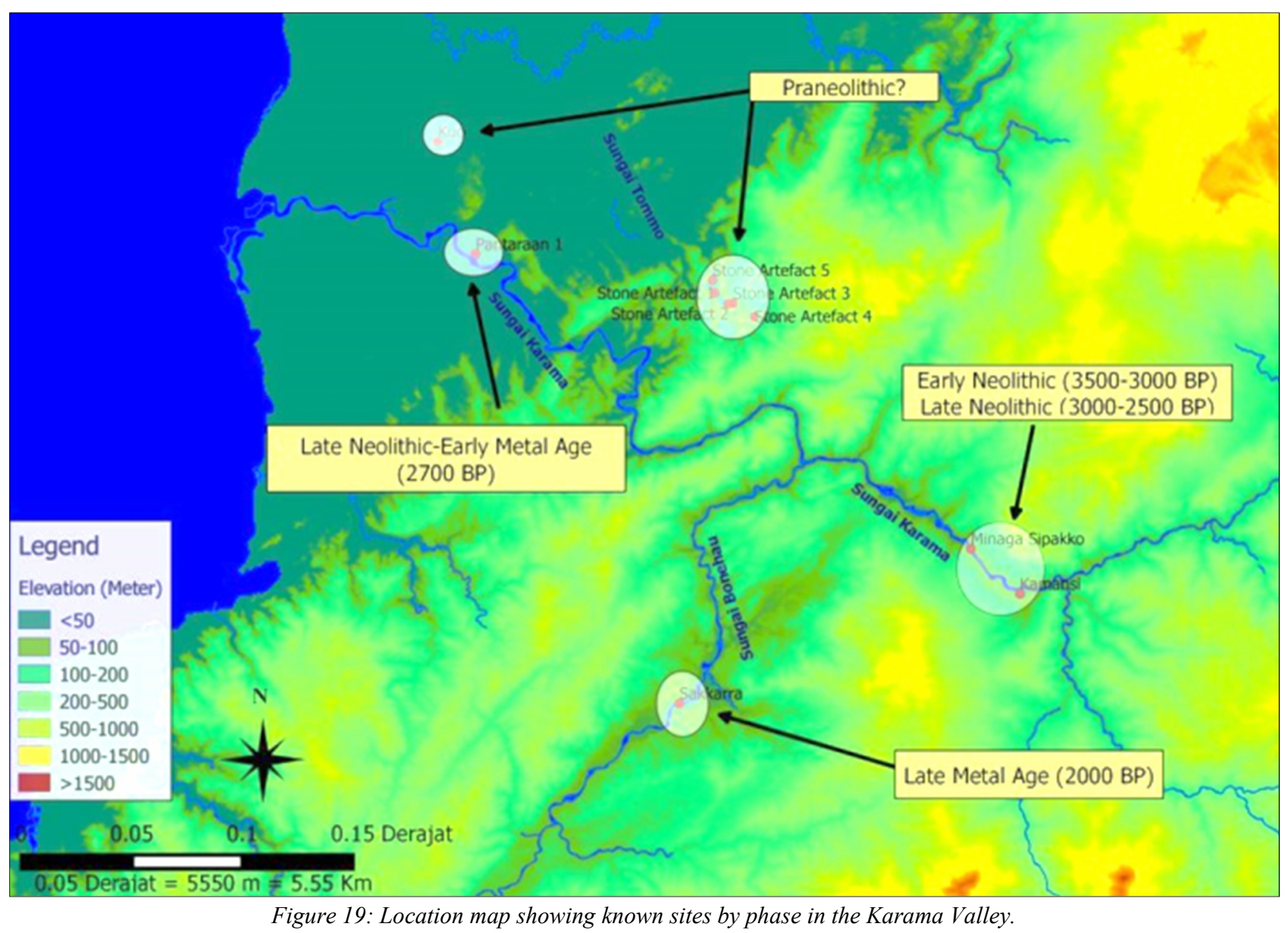

assemblage of about 2000 years ago, thus well within the Metal Age.

The quantities of potsherds were greatest between spits 6 and 9, and dropped sharply below 11 (Table 3 and Figure 14). Iron and glass beads showed similar distributions, and a glass bracelet was found in spit 7 (Figure 15). Polished stone fragments were found in spits 10 and 11 . One of the site highlights was a starshaped mace-like sandstone object, $10 \mathrm{~cm}$ in outer diameter, with a central perforation $3 \mathrm{~cm}$ in diameter (Figure 17).

Analysis of 501 pottery rims (Table 5 and Figure 18) reveals forms such as restricted vessels with everted rims, unrestricted bowls on pedestals, vertical spouts, and large open direct rimmed vessels that might have served as burial jars. There are 3785 non-rim sherds, dominated by body sherds, of which 2019 (53.34\%) are of medium thickness $(4-8 \mathrm{~mm}), 1546(40.85 \%)$ are thin $(1-4 \mathrm{~mm})$, and only $220(5.81 \%)$ are thick over $8 \mathrm{~mm})$. Only 8 sherds $(0.21 \%)$ revealed red slipped surfaces.

To date, pre-Neolithic sites are only known to the north of the Karama River, at Bukit Kuo and along the Tommo River. Simanjuntak's (1994, 2007) previous research results suggested two phases of Neolithic occupation, with an Early Neolithic dated 3500-3000 BP with red slipped pottery, bone points and stone axe/adzes, especially at Minanga Sipakko. The results of Hakim and Suryatman at Kamansi also consisted of red slipped pottery, a green stone (not nephrite) pendant, axe/adzes (some perforated), limestone bracelet fragments, hammerstones, grindstones, and some shell artifacts (Hakim and Suryatman 2012).

The Late Neolithic, dated 3000-2500 BP, continued in the Kalumpang region with a replacement of the red slipped pottery by plain wares. Simanjuntak's research also shows a presence of obsidian artifacts. The quantities of pottery at Kamansi increased dramatically during the late Neolithic (Hakim and Suryatman 2012), possibly reflecting an increase in population.

The initial Metal Age occurs downstream in the upper layer of Pantaraan I, above another late Neolithic occupation with plain ware dated to about $2700 \mathrm{BP}$. No obsidian was found here (Anggraeni 2012: 120-135; Anggraeni et al. 2014). The Metal Age at Sakkarra in the Bonehau Valley is dated to $2000 \mathrm{BP}$, here associated with unslipped pottery, glass beads and metal. No stone flakes were found on this site. A summary of the currently known Karama valley site distribution is given in Figure 19.

Recommendations for subsequent research are as follows:

1. The exploration for pre-Neolithic sites on the north side of the Karama watershed should be extended into the Lumu River basin, a branch of the Tommo.

2. Horizontal excavation needs to be pursued at Sakkarra. 
3. Lemo Lemo 3 has many varied surface finds and should be excavated.

\section{ACKNOWLEDGEMENTS}

This study would not have been possible without the help of various individuals and institutions. Funding for this research came from The Anthony F. Granucci Fund for Archaeological Research in Indonesia and East Timor. Our thanks go to the Head of the Archaeological Institute of Makassar, Dr Gusti Made Sudarmika, who gave permission for the use of a work area and office, also to Andi Muhammad Saiful Hasrianti and Arizal Purnama who helped during the fieldwork. Dr Philip Piper helped us to obtain the two ${ }^{14} \mathrm{C}$ dates from ANU.

\section{REFERENCES}

Anggraeni 2012. The Austronesian Migration Hypothesis as seen from Prehistoric Settlements on the Karama River. Mamuju, West Sulawesi. Unpublished PhD dissertation, Australian National University.

Anggraeni, Simanjuntak, T., Bellwood, P. and Piper, P. 2014. Neolithic foundations in the Karama Valley, West Sulawesi, Indonesia. Antiquity 88:740-56.

Anon. 2011. Laporan Penelitian Arkeologi Situs Bukit Kamansi, Kalumpang, Kabupaten Mamuju, Sulawesi Barat. Unpublished report in Indonesian. Balai Arkeologi Makassar, Makassar.

Anon. 2012. Laporan Penelitian Arkeologi Situs Bukit Kamansi, Kalumpang, Kabupaten Mamuju, Sulawesi Barat. Unpublished report in Indonesian. Makassar: Balai Arkeologi Makassar.

Hakim, B. and Suryatman 2012. Eksistensi Penutur Austronesia di Situs Kamansi, Kalumpang, Kabupaten Mamuju, Sulawesi Barat. Unpublished report in Indonesian. Makassar: Balai Arkeologi Makassar.

Simanjuntak, T. 1994. Kalumpang: Hunian Sungai Bercorak Neolitik-Paleometalik di Pedalaman Sulawesi Selatan. Aspek-aspek Arkeologi Indonesia. No. 17. Jakarta: Pusat Penelitian Arkeologi Indonesia.

Simanjuntak, T. 2007. Arkeologi dan Etnografi Kalumpang, Kabupaten Mamuju, Propinsi Sulawesi Barat. Jakarta: Pusat Penelitian Arkeologi Nasional. 